\title{
Thermophysical Properties of Heat Resistant Shielding Material
}

\section{December 2004}

W. D. Porter

H. Wang 


\title{
DOCUMENT AVAILABILITY
}

Reports produced after January 1, 1996, are generally available free via the U.S. Department of Energy (DOE) Information Bridge:

Web site: http://www.osti.gov/bridge

Reports produced before January 1, 1996, may be purchased by members of the public from the following source:

\author{
National Technical Information Service \\ 5285 Port Royal Road \\ Springfield, VA 22161 \\ Telephone: 703-605-6000 (1-800-553-6847) \\ TDD: 703-487-4639 \\ Fax: 703-605-6900 \\ E-mail: info@ntis.fedworld.gov \\ Web site: http://www.ntis.gov/support/ordernowabout.htm
}

Reports are available to DOE employees, DOE contractors, Energy Technology Data Exchange (ETDE) representatives, and International Nuclear Information System (INIS) representatives from the following source:

Office of Scientific and Technical Information

P.O. Box 62

Oak Ridge, TN 37831

Telephone: 865-576-8401

Fax: 865-576-5728

E-mail: reports@adonis.osti.gov

Web site: http://www.osti.gov/contact.html

\begin{abstract}
This report was prepared as an account of work sponsored by an agency of the United States Government. Neither the United States government nor any agency thereof, nor any of their employees, makes any warranty, express or implied, or assumes any legal liability or responsibility for the accuracy, completeness, or usefulness of any information, apparatus, product, or process disclosed, or represents that its use would not infringe privately owned rights. Reference herein to any specific commercial product, process, or service by trade name, trademark, manufacturer, or otherwise, does not necessarily constitute or imply its endorsement, recommendation, or favoring by the United States Government or any agency thereof. The views and opinions of authors expressed herein do not necessarily state or reflect those of the United States Government or any agency thereof.
\end{abstract}


Metals and Ceramics Division

\title{
THERMOPHYSICAL PROPERTIES OF HEAT RESISTANT SHIELDING MATERIAL
}

\author{
W. D. Porter and H. Wang
}

Date Published: December 2004

Prepared by

OAK RIDGE NATIONAL LABORATORY

Oak Ridge, TN 37831-6285

managed by

UT-BATTELLE LLC

for the

U.S. DEPARTMENT OF ENERGY

under contract DE-AC05-00OR22725 



\section{CONTENTS}

Page

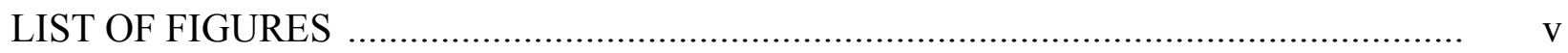

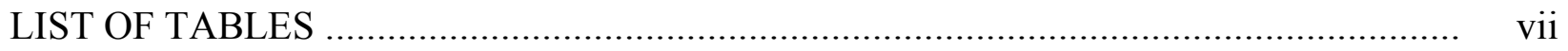

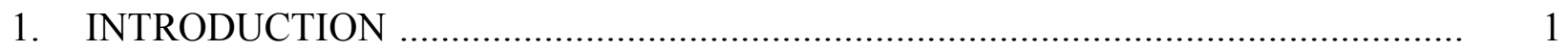

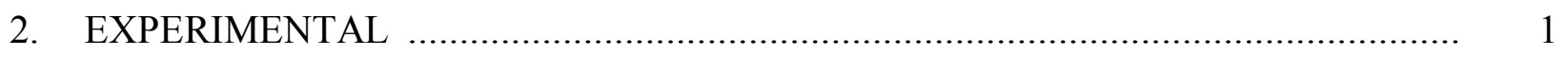

2.1 THERMAL CONDUCTIVITY AND VOLUMETRIC SPECIFIC HEAT ............ 1

2.2 THERMAL EXPANSION ....................................................................... 2

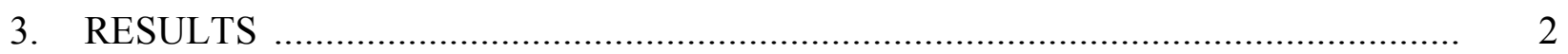

3.1 THERMAL CONDUCTIVITY AND VOLUMETRIC SPECIFIC HEAT ............ 2

3.2 THERMAL EXPANSION ....................................................................... 6

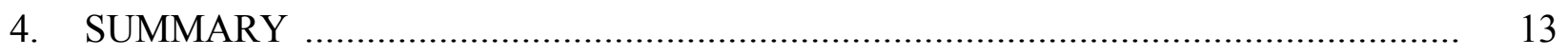

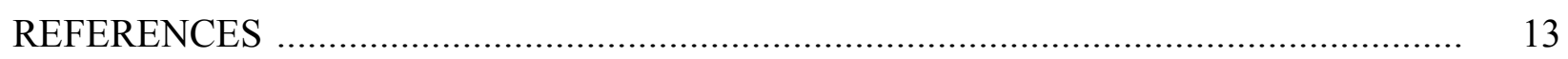





\section{LIST OF FIGURES}

Figure

Page

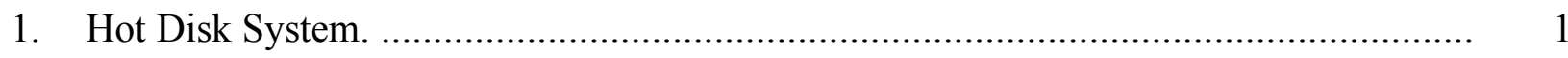

2. Thermal conductivity of Thermo Electron RM\&P Catalog No. 277-4. ....................... 3

3. Volumetric specific heat vs. temperature. .................................................. 4

4. Average thermal conductivity of Thermo Electron RM\&P No. 277-4. ..................... 5

5. Average volumetric specific heat of Thermo Electron RM\&P Catalog No. 277-4. ...... 6

6. Thermal expansion of Type 277-4 cement material as a function of temperature. ........ 7

7. Comparison of smoothed data and cubic spline fit of smoothed data to raw pooled experimental data for thermal expansion of Type 277-4 cement material as a function of temperature.

8. Relative residuals of cubic spline fit used to estimate expansion values tabulated in Table 5.

9. Comparison of MCTE calculated from estimated expansion with MCTE calculated from smoothed expansion data and raw pooled MCTE values.

10. Relative residuals of the $9^{\text {th }}$ order polynomial fit of the estimated MCTE values using 8 significant digits for the coefficients as shown in Equation 2. 



\section{LIST OF TABLES}

Table

Page

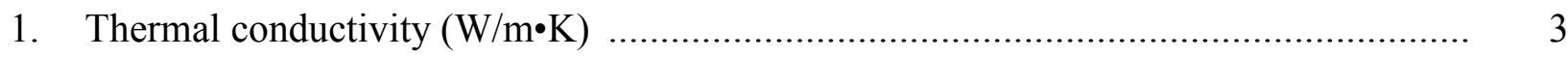

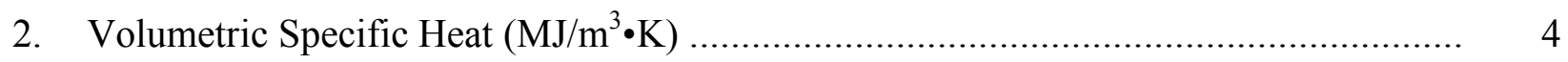



4. Measured thermal expansion values and Mean CTE for

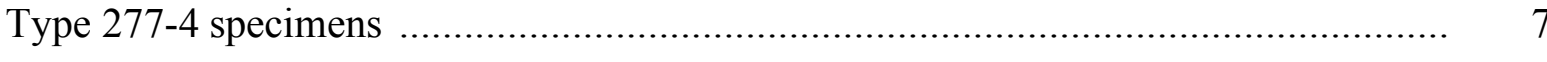

5. Expansion values at even intervals estimated from cubic spline fit of pooled,

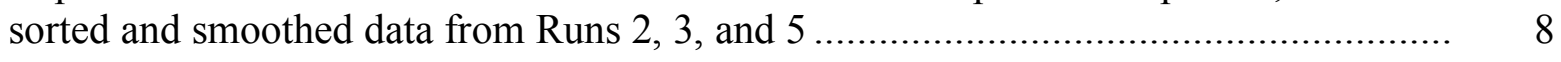

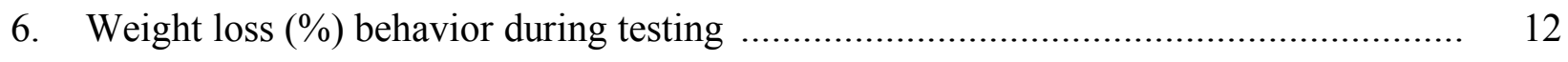

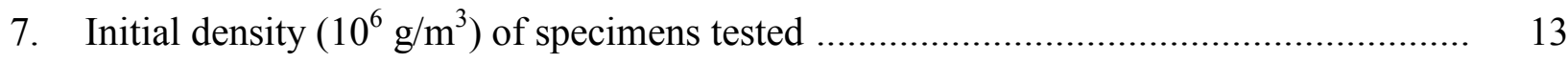





\section{INTRODUCTION}

This project was aimed at determining thermal conductivity, specific heat and thermal expansion of a heat resistant shielding material for neutron absorption applications. These data are critical in predicting the structural integrity of the shielding under thermal cycling and mechanical load. The measurements of thermal conductivity and specific heat were conducted in air at five different temperatures $\left(-31^{\circ} \mathrm{F}, 73.4^{\circ} \mathrm{F}, 140^{\circ} \mathrm{F}, 212^{\circ} \mathrm{F}\right.$ and $\left.302^{\circ} \mathrm{F}\right)$. The transient plane source (TPS) method was used in the tests. Thermal expansion tests were conducted using push rod dilatometry over the continuous range from $-40^{\circ} \mathrm{F}\left(-40^{\circ} \mathrm{C}\right)$ to $302^{\circ} \mathrm{F}\left(150^{\circ} \mathrm{C}\right)$.

\section{EXPERIMENTAL}

\subsection{THERMAL CONDUCTIVITY AND VOLUMETRIC SPECIFIC HEAT}

The Hot Disk Thermal Constants Analyzer was used to measure both thermal conductivity and specific heat of the samples. ${ }^{1-3}$ The recently upgraded system (Fig. 1) uses a bridge to balance out changes in heater resistance at different temperatures. Two samples are needed for the measurement. A Kapton sensor/heater is sandwiched between the two samples. For the heat resistant shielding material, each measurement took $80 \mathrm{~s}$ during which the interface was heated up by a constant power output of $0.05 \mathrm{~W}$. The overall temperature rise was kept under $5^{\circ} \mathrm{C}$. Thermal conductivity and volumetric specific heat can be calculated from the interface temperature vs. time plot using the Hot Disk ${ }^{\circledR}$ software.

Six heat resistant shielding samples, Thermo Electron RM\&P Catalog No. 277-4, were provided and were paired up in random. Each pair was measured at room temperature at HTML. The system was then taken to Building 4508 where a freezer $\left(a t-31^{\circ} \mathrm{F}\right)$ was available. After the freezer test, the specimens were tested in a box furnace at three elevated temperatures. To reach thermal equilibrium, the specimens were left in the freezer or furnace for at least $2.5 \mathrm{hr}$ before measurements were started.

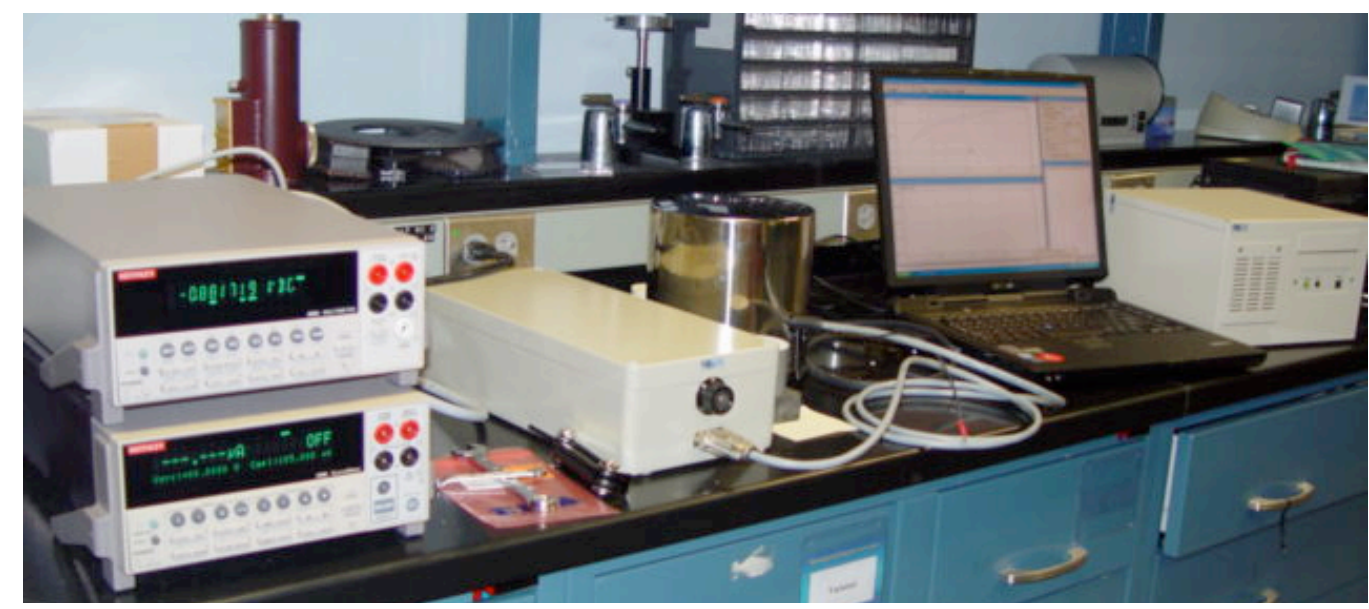

Fig. 1. Hot Disk System. 


\subsection{THERMAL EXPANSION}

Specimens of cast Type 277-4 cement were received and tested by staff of the High Temperature Materials Laboratory at ORNL. The specimens were received in two shipments and consisted of three separate pours (lots) of the material. Lot 1 contained one specimen, poured in a one-piece mold, and having a diameter of $\sim 5.5 \mathrm{~mm}$. Lot 2 contained 7 specimens, poured in a split two-piece mold, also with a diameter of $\sim 5.5 \mathrm{~mm}$. Lot 3 had 5 specimens with a diameter of $\sim 12.5 \mathrm{~mm}$. No specimens from Lot 3 were used for measurements. The nominal length of all specimens was $25 \mathrm{~mm}$.

Thermal expansion measurements were conducted using a Theta Industries dual push rod dilatometer. The testing followed the constant ramping procedure of ASTM E-228 for "Linear Thermal Expansion of Solid Materials with a Vitreous Silica Dilatometer."4 A cryogenic furnace, cooled with helium gas bubbled through liquid nitrogen and heated by nichrome wires, was used with a silica specimen holder and push rods. A type $\mathrm{K}$ thermocouple in direct contact with the specimen was used to measure the specimen temperature. NIST Tungsten SRM 737 was used for the reference standard in the differential measurements. The specimens were tested over the range of $-40^{\circ} \mathrm{C}$ to $150^{\circ} \mathrm{C}$ using heating rates of $3^{\circ} \mathrm{C} / \mathrm{min}$. The reference temperature for all expansion calculations was $20^{\circ} \mathrm{C}$. A $5 \mathrm{cc} / \mathrm{min}$ flowrate of helium was used inside the specimen enclosure during the tests. This was a separate stream of helium from that used for cooling the cryogenic furnace. The displacements of the specimen and reference rods were determined by an LVDT housed in a constant temperature enclosure which also contained the RTD used for cold junction compensation of the specimen thermocouple signal.

The temperature schedule for the measurement tests was as follows:

1. Cool specimen to $\sim 15^{\circ} \mathrm{C}$ prior to starting test using cooled helium.

2. Start data collection and heat specimen to $40^{\circ} \mathrm{C}$. (Expansion is automatically zeroed as the specimen temperature goes through the $20^{\circ} \mathrm{C}$ reference temperature.)

3. Cool to $-40^{\circ} \mathrm{C}$ at a nominal rate of $3^{\circ} \mathrm{C} / \mathrm{min}$.

4. Heat to $150^{\circ} \mathrm{C}$.

5. Cool to $-40^{\circ} \mathrm{C}$ at a nominal rate of $3^{\circ} \mathrm{C} / \mathrm{min}$.

6. Heat to $25^{\circ} \mathrm{C}$ and end test.

The schedule used allowed any hysteresis of the specimen expansion behavior to be noted.

\section{RESULTS}

\subsection{THERMAL CONDUCTIVITY AND VOLUMETRIC SPECIFIC HEAT}

Thermal conductivity values of the three pairs of samples are shown in Table 1 and the Thermal Conductivity vs. Temperature plot is shown in Fig. 2. Three measurements were taken at each temperature for each pair of samples. There is some scatter among the pairs $(<5 \%$ between 3 measurements at the same temperature, 3-10\% among the pairs) but they all showed similar changes over the temperature range. Since the specimens had to be taken out several times at each temperature, their exposure to air and thermal cycles was not controlled. 
Table 1. Thermal conductivity $(\mathrm{W} / \mathrm{m} \cdot \mathrm{K})$

\begin{tabular}{|c|c|c|c|}
\hline Temperature (F) & Pair A & Pair B & Pair C \\
\hline-31 & 0.96 & 0.97 & 0.92 \\
\hline 73.4 & 1.00 & 0.97 & 1.05 \\
\hline 140 & 0.87 & 0.75 & 0.87 \\
\hline 212 & 0.64 & 0.62 & 0.58 \\
\hline 302 & 0.67 & 0.59 & 0.64 \\
\hline
\end{tabular}

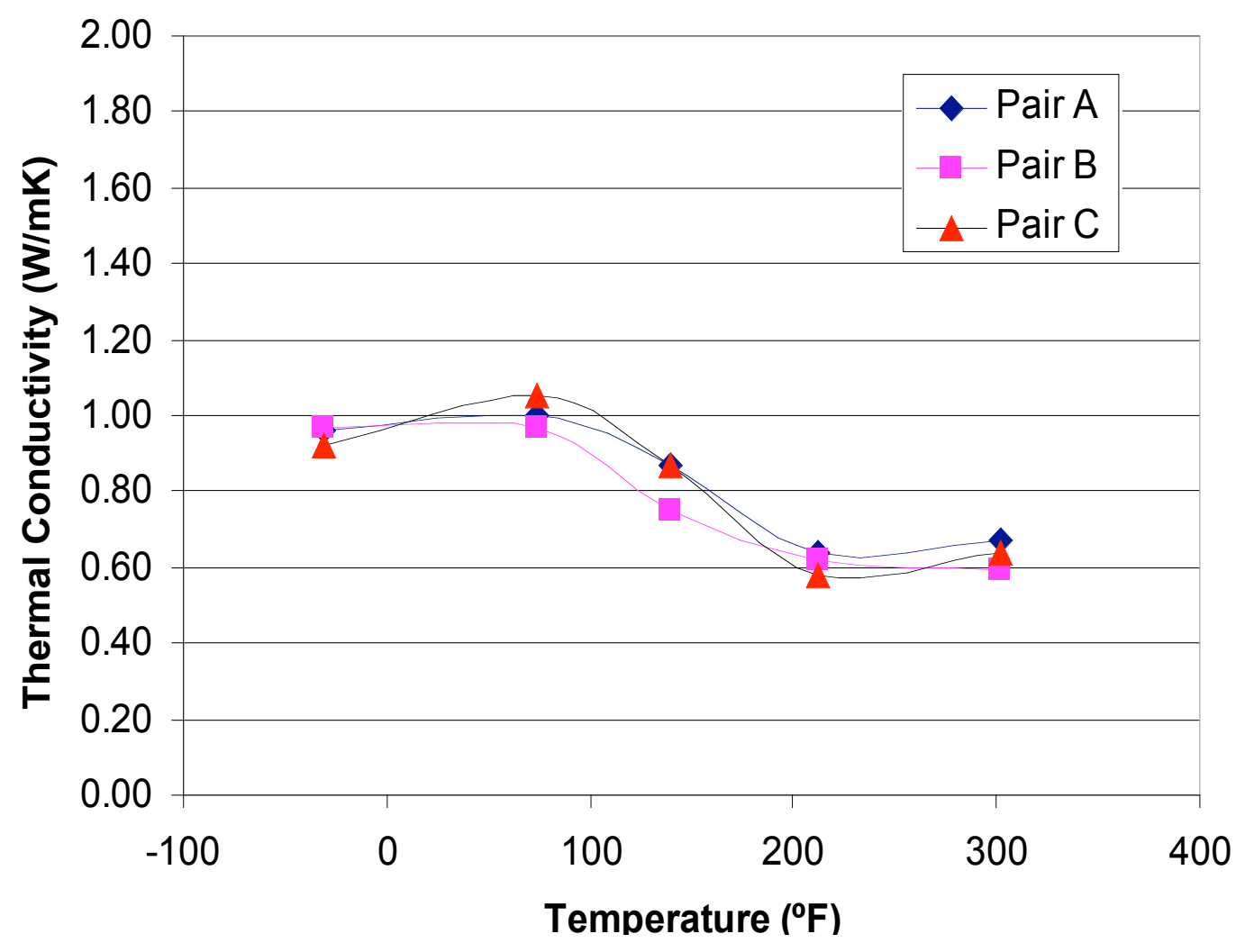

Fig 2. Thermal conductivity of Thermo Electron RM\&P Catalog No. 277-4.

The volumetric specific heats were also obtained in the calculation. The value is a product of specific heat and density with the unit of $10^{6} \mathrm{~J} / \mathrm{m}^{3} \cdot \mathrm{K}$, as shown in Table 2 and Fig. 3 . Since the weight of the samples exceeded the limit of the balance in the lab we were not able to measure the density of the specimens accurately. If the density is known $\left(1.68^{*} 10^{6} \mathrm{~g} / \mathrm{m}^{3}\right.$ from product literature), the specific heat values can be calculated simply by dividing the current experimental value by density. 
Table 2. Volumetric Specific Heat $\left(\mathrm{MJ} / \mathrm{m}^{3} \cdot \mathrm{K}\right)$

\begin{tabular}{|c|c|c|c|}
\hline Temperature (F) & Pair A & Pair B & Pair C \\
\hline-31 & 0.92 & 0.80 & 0.92 \\
\hline 73.4 & 1.33 & 1.27 & 1.32 \\
\hline 140 & 1.71 & 1.68 & 1.65 \\
\hline 212 & 1.72 & 1.67 & 1.72 \\
\hline 302 & 1.99 & 2.14 & 2.01 \\
\hline
\end{tabular}

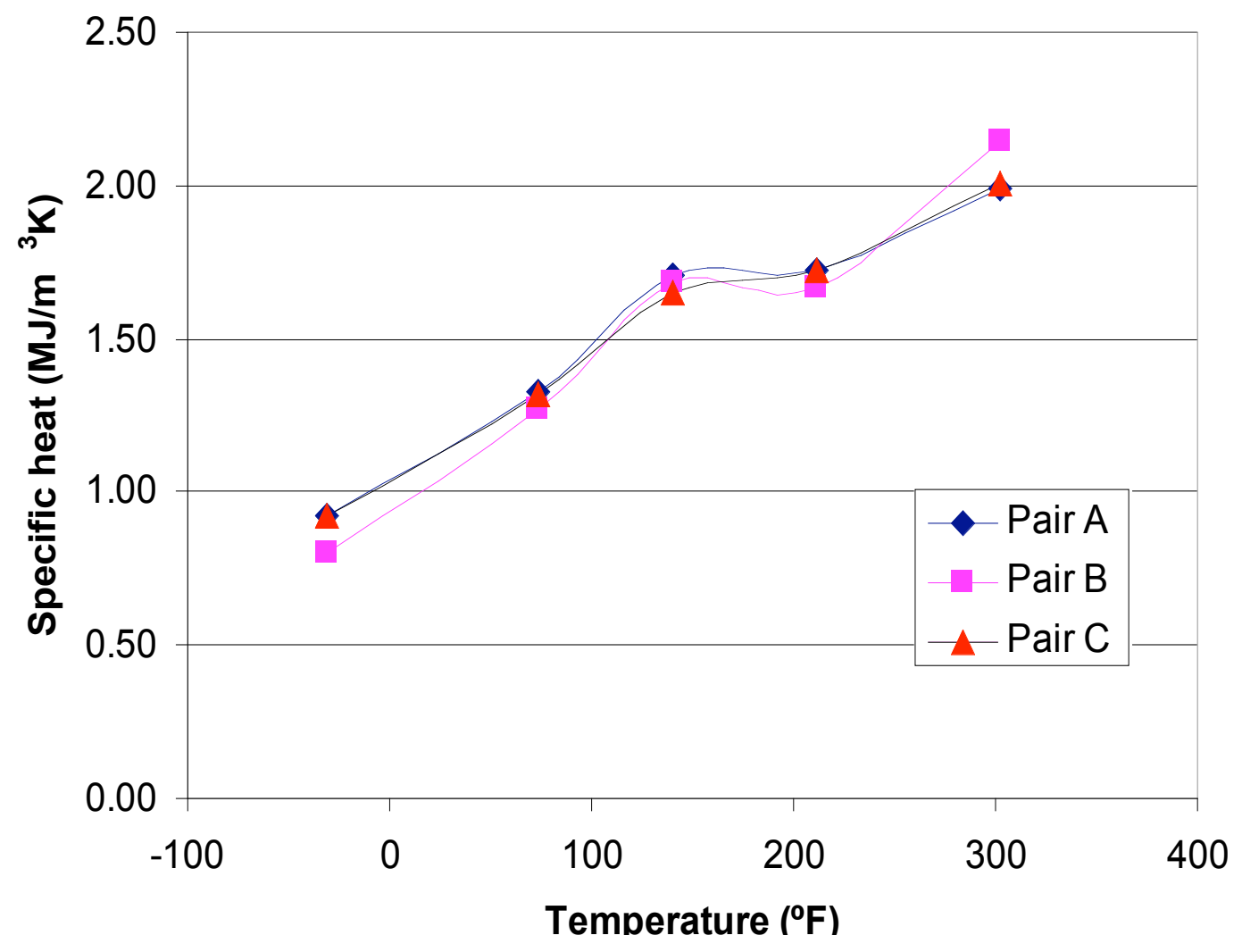

Fig. 3. Volumetric specific heat vs. temperature.

Since the three pairs of specimens were randomly grouped, we averaged the results to show the material properties. The values are shown in Table 3 and the plots are shown in Figures 4-5. 
Table 3. Average values of $k$ and $C p$

\begin{tabular}{|c|c|c|}
\hline Temperature $\left({ }^{\circ} \mathrm{F}\right)$ & $\begin{array}{c}\text { Average } \mathrm{k} \\
(\mathrm{W} / \mathrm{m} \cdot \mathrm{K})\end{array}$ & $\begin{array}{c}\text { Average Cp } \\
\left(\mathrm{MJ} / \mathrm{m}^{3} \cdot \mathrm{K}\right)\end{array}$ \\
\hline-31 & 0.95 & 0.88 \\
\hline 73.4 & 1.01 & 1.31 \\
\hline 140 & 0.83 & 1.68 \\
\hline 212 & 0.61 & 1.70 \\
\hline 302 & 0.63 & 2.05 \\
\hline
\end{tabular}

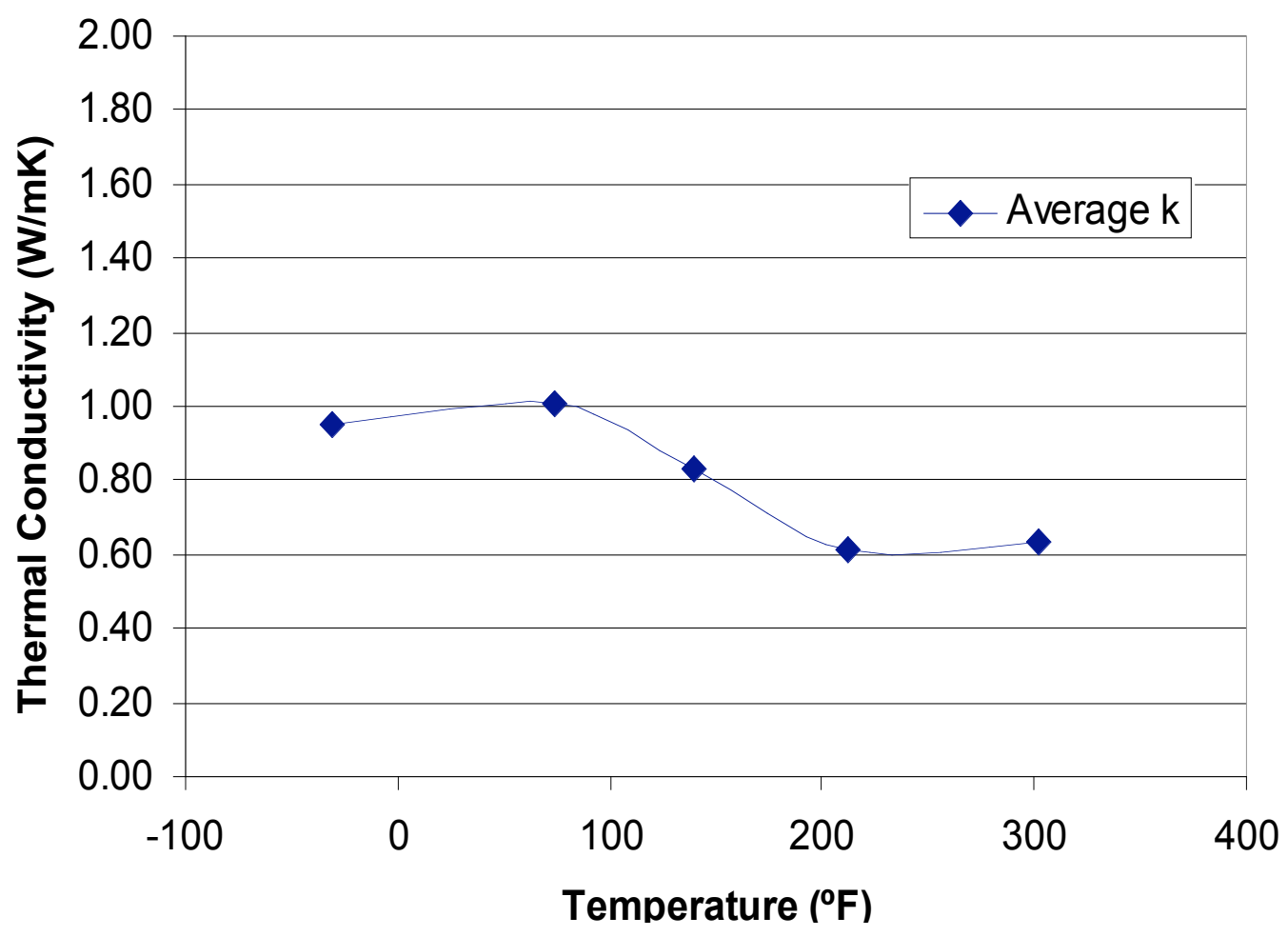

Fig. 4. Average thermal conductivity of Thermo Electron RM\&P No. 277-4. 


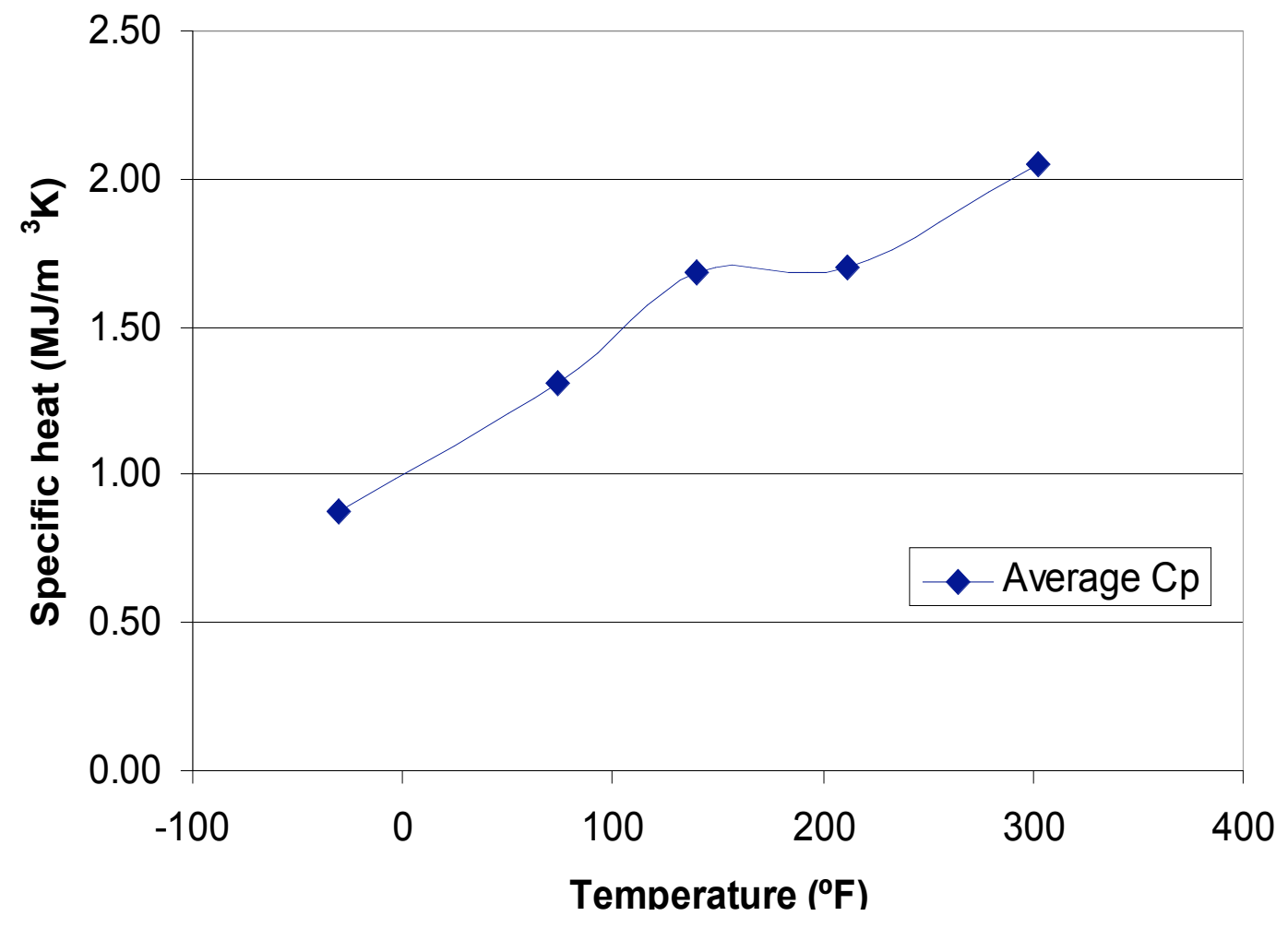

Fig. 5. Average volumetric specific heat of Thermo Electron RM\&P Catalog No. 277-4.

\subsection{THERMAL EXPANSION}

One specimen from Lot 1 and four specimens from Lot 2 were tested. The thermal expansion results of the five specimens are shown in Fig. 6. Three Lot 2 specimen results grouped almost on top of each other. The fourth Lot 2 specimen deviated from the other three at temperatures greater than about $100^{\circ} \mathrm{C}$. The single specimen from Lot 1 behaved markedly different than the Lot 2 specimens when heated above $50^{\circ} \mathrm{C}$. The expansion behavior during cooling was very similar for all five specimens tested. All specimens tested exhibited a permanent strain (shrinkage) as a result of heating above $50^{\circ} \mathrm{C}$. Measured data for the expansion of the five specimens taken from the initial heating from $-40^{\circ} \mathrm{C}$ to $150^{\circ} \mathrm{C}$ can be found in Table 4. Also shown in Table 4 are values for the Mean Coefficient of Thermal Expansion (MCTE) calculated from $20^{\circ} \mathrm{C}$. MCTE is defined as:

$$
\mathrm{MCTE}=(\text { expansion @ T }) /(\mathrm{T}-20)
$$

where $\mathrm{T}$ is the temperature in ${ }^{\circ} \mathrm{C}$. 


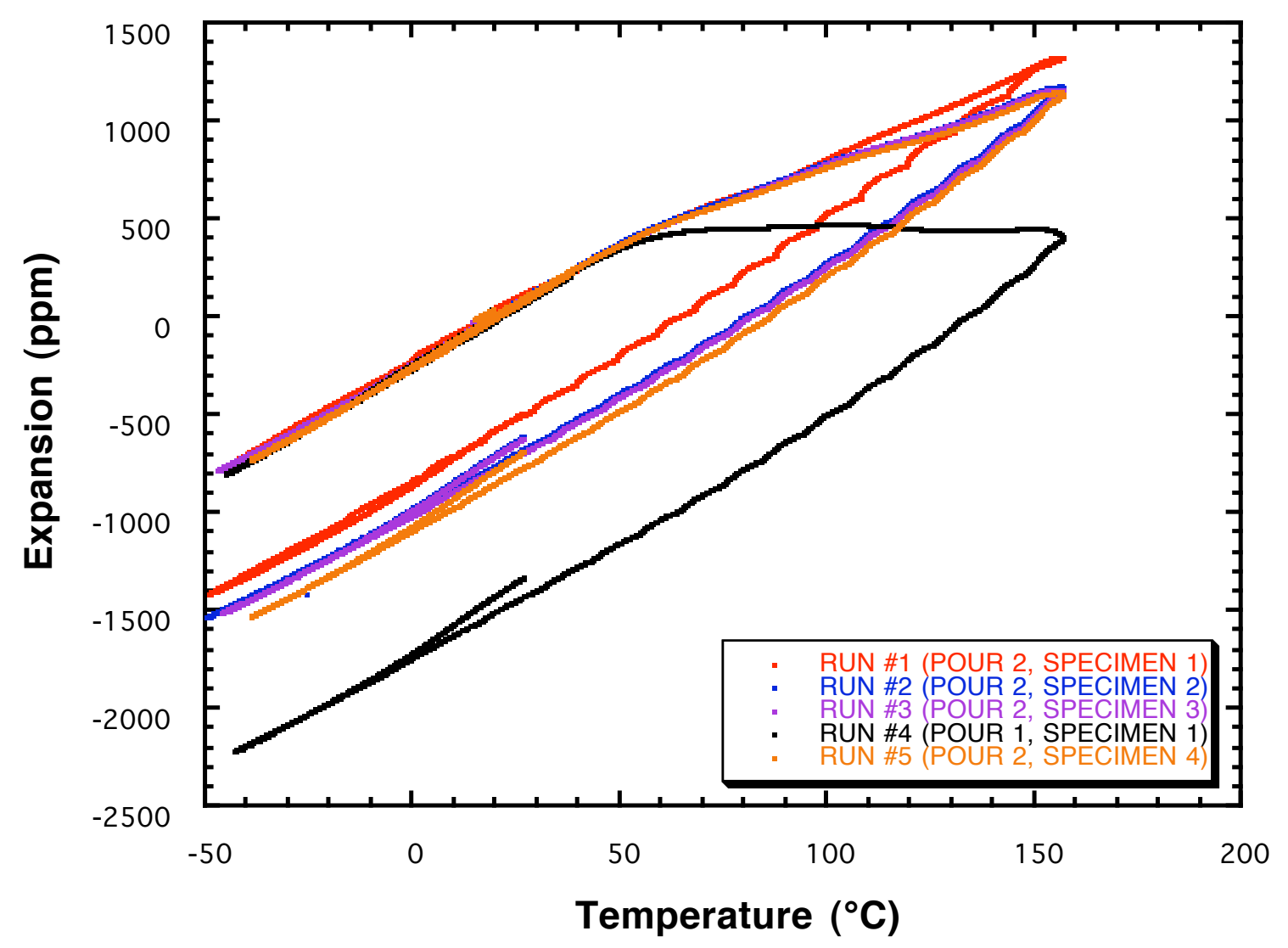

Fig. 6. Thermal expansion of Type 277-4 cement material as a function of temperature.

Table 4. Measured thermal expansion values and Mean CTE for Type 277-4 specimens

\begin{tabular}{|c|c|c|c|c|c|c|c|c|c|c|}
\hline \multirow{2}{*}{$\begin{array}{c}\text { Temperature, } \\
{ }^{\circ} \mathrm{C}\end{array}$} & \multicolumn{2}{|c|}{ Run \#1 } & \multicolumn{2}{c|}{ Run \#2 } & \multicolumn{2}{c|}{ Run \#3 } & \multicolumn{2}{c|}{ Run \#4 } & \multicolumn{3}{c|}{ Run \#5 } \\
\hline-40 & $\begin{array}{c}\text { exp, } \\
\mathrm{ppm}\end{array}$ & $\begin{array}{l}\mathrm{MCTE}, \\
\mathrm{ppm} /{ }^{\circ} \mathrm{C}\end{array}$ & $\begin{array}{l}\text { exp, } \\
\mathrm{ppm}\end{array}$ & $\begin{array}{l}\mathrm{MCTE}, \\
\mathrm{ppm} /{ }^{\circ} \mathrm{C}\end{array}$ & $\begin{array}{l}\text { exp, } \\
\mathrm{ppm}\end{array}$ & $\begin{array}{l}\mathrm{MCTE}, \\
\mathrm{ppm} /{ }^{\circ} \mathrm{C}\end{array}$ & $\begin{array}{l}\text { exp, } \\
\mathrm{ppm}\end{array}$ & $\begin{array}{l}\mathrm{MCTE}, \\
\mathrm{ppm} /{ }^{\circ} \mathrm{C}\end{array}$ & $\begin{array}{l}\text { exp, } \\
\mathrm{ppm}\end{array}$ & $\begin{array}{l}\mathrm{MCTE}, \\
\mathrm{ppm} /{ }^{\circ} \mathrm{C}\end{array}$ \\
\hline-741 & 12.4 & -727 & 12.1 & -725 & 12.1 & -759 & 12.6 & -753 & 12.6 \\
\hline 0 & -517 & 12.9 & -500 & 12.5 & -498 & 12.4 & -519 & 13.0 & -520 & 13.0 \\
\hline 20 & -266 & 13.3 & -251 & 12.6 & -247 & 12.3 & -251 & 12.5 & -260 & 13.0 \\
\hline 40 & 0 & & 0 & & 0 & & 0 & & 0 & \\
\hline 60 & 239 & 12.0 & 252 & 12.6 & 245 & 12.3 & 240 & 12.0 & 248 & 12.4 \\
\hline 80 & 628 & 11.6 & 466 & 11.6 & 455 & 11.4 & 410 & 10.2 & 458 & 11.5 \\
\hline 100 & 797 & 10.5 & 622 & 10.4 & 611 & 10.2 & 448 & 7.5 & 605 & 10.1 \\
\hline 120 & 983 & 9.8 & 778 & 9.7 & 772 & 9.7 & 465 & 5.8 & 757 & 9.5 \\
\hline 140 & 1166 & 9.7 & 1050 & 8.1 & 905 & 9.1 & 447 & 4.5 & 882 & 8.8 \\
\hline 150 & 1271 & 9.8 & 1136 & 8.7 & 1126 & 8.7 & 449 & 3.4 & 1108 & 8.5 \\
\hline
\end{tabular}


The expansion data in the interval -40 to $150^{\circ} \mathrm{C}$ for 3 of the Lot 2 specimens (Run \#2, \#3 and \#5) were pooled and then sorted in ascending order by temperature. A moving average smoothing routine with a 31-point window (corresponds to less than $1{ }^{\circ} \mathrm{C}$ temperature interval) was used to smooth both the temperature and expansion data. A cubic spline fit through this pooled, sorted and smoothed data set was then used to generate values for the expansion at increments of $1^{\circ} \mathrm{C}$ as shown in Table 5. The spline fit indicated an expansion of $1.6 \mathrm{ppm}$ at $20^{\circ} \mathrm{C}$. Since by definition the expansion is zero at the $20^{\circ} \mathrm{C}$ reference temperature, the values of Table 5 have been offset by this amount.

Table 5. Expansion values at even intervals estimated from cubic spline fit of pooled, sorted and smoothed data from Runs 2, 3, and 5.

\begin{tabular}{|c|c|c|}
\hline $\begin{array}{c}\text { TEMPERATURE, } \\
{ }^{\circ} \mathrm{C}\end{array}$ & $\begin{array}{l}\text { ESTIMATED } \\
\text { EXPANSION, } \\
\text { ppm }\end{array}$ & $\begin{array}{l}\text { ESTIMATED } \\
\mathrm{MCTE}, \\
\mathrm{ppm} /{ }^{\circ} \mathrm{C}\end{array}$ \\
\hline-37 & -706 & 12.4 \\
\hline-36 & -695 & 12.4 \\
\hline-35 & -683 & 12.4 \\
\hline-34 & -671 & 12.4 \\
\hline-33 & -661 & 12.5 \\
\hline-32 & -649 & 12.5 \\
\hline-31 & -638 & 12.5 \\
\hline-30 & -625 & 12.5 \\
\hline-29 & -614 & 12.5 \\
\hline-28 & -603 & 12.6 \\
\hline-27 & -591 & 12.6 \\
\hline-26 & -578 & 12.6 \\
\hline-25 & -567 & 12.6 \\
\hline-24 & -555 & 12.6 \\
\hline-23 & -544 & 12.7 \\
\hline-22 & -532 & 12.7 \\
\hline-21 & -519 & 12.7 \\
\hline-20 & -508 & 12.7 \\
\hline-19 & -496 & 12.7 \\
\hline-18 & -484 & 12.7 \\
\hline-17 & -470 & 12.7 \\
\hline-16 & -458 & 12.7 \\
\hline-15 & -446 & 12.8 \\
\hline-14 & -433 & 12.8 \\
\hline-13 & -420 & 12.8 \\
\hline-12 & -408 & 12.8 \\
\hline-11 & -395 & 12.7 \\
\hline-10 & -382 & 12.8 \\
\hline-9 & -369 & 12.7 \\
\hline-8 & -356 & 12.7 \\
\hline-7 & -344 & 12.7 \\
\hline-6 & -331 & 12.7 \\
\hline-5 & -317 & 12.7 \\
\hline-4 & -304 & 12.7 \\
\hline-3 & -292 & 12.7 \\
\hline-2 & -279 & 12.7 \\
\hline-1 & -267 & 12.7 \\
\hline 0 & -254 & 12.7 \\
\hline 1 & -241 & 12.7 \\
\hline 2 & -228 & 12.7 \\
\hline 3 & -216 & 12.7 \\
\hline 4 & -203 & 12.7 \\
\hline
\end{tabular}

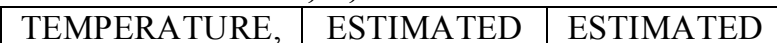

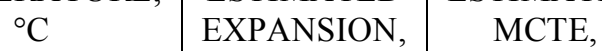

\begin{tabular}{|c|c|c|} 
& $\mathrm{ppm}$ & $\mathrm{ppm} /{ }^{\circ} \mathrm{C}$ \\
\hline 5 & -190 & 12.7 \\
\hline 6 & -177 & 12.7 \\
\hline 7 & -165 & 12.7 \\
\hline 8 & -152 & 12.7 \\
\hline 9 & -139 & 12.7 \\
\hline
\end{tabular}

\begin{tabular}{|c|c|c|}
\hline 9 & -139 & 12.7 \\
\hline 10 & -126 & 12.7 \\
\hline 11 & -114 & 12.7 \\
\hline
\end{tabular}

\begin{tabular}{|c|c|c|}
\hline 11 & -114 & 12.7 \\
\hline 12 & -101 & 12.7 \\
\hline 13 & -88 & 12.7 \\
\hline 14 & -76 & 12.7 \\
\hline
\end{tabular}

\begin{tabular}{|c|c|c|}
\hline 13 & -88 & 12.7 \\
\hline 14 & -76 & 12.7 \\
\hline 15 & -63 & 12.6 \\
\hline 16 & -50 & 12.6 \\
\hline 17 & -37 & 12.6 \\
\hline
\end{tabular}

\begin{tabular}{|c|c|c|}
\hline 17 & -37 & 12.6 \\
\hline 18 & -25 & 12.6 \\
\hline 19 & -12 & 12.6 \\
\hline 20 & 0 & 12.6 \\
\hline 21 & 12 & 12.6 \\
\hline 22 & 25 & 12.6 \\
\hline 23 & 38 & 12.7 \\
\hline 24 & 50 & 12.6 \\
\hline 25 & 63 & 12.6 \\
\hline 26 & 75 & 12.6 \\
\hline 27 & 88 & 12.6 \\
\hline 28 & 100 & 12.6 \\
\hline 29 & 113 & 12.6 \\
\hline 30 & 125 & 12.5 \\
\hline 31 & 137 & 12.5 \\
\hline 32 & 150 & 12.5 \\
\hline 33 & 162 & 12.5 \\
\hline 34 & 174 & 12.5 \\
\hline 35 & 186 & 12.4 \\
\hline 36 & 198 & 12.4 \\
\hline 37 & 210 & 12.4 \\
\hline 38 & 222 & 12.4 \\
\hline 39 & 235 & 12.4 \\
\hline 40 & 246 & 12.3 \\
\hline 41 & 258 & 12.3 \\
\hline 42 & 270 & 12.3 \\
\hline 43 & 281 & 12.3 \\
\hline 44 & 293 & 12.2 \\
\hline 45 & 305 & 12.2 \\
\hline 46 & 316 & 12.2 \\
\hline & & \\
\hline 83 & & -50 \\
\hline
\end{tabular}


Table 5. (Continued)

\begin{tabular}{|c|c|c|c|c|c|}
\hline $\begin{array}{c}\text { TEMPERATURE, } \\
{ }^{\circ} \mathrm{C}\end{array}$ & $\begin{array}{c}\text { ESTIMATED } \\
\text { EXPANSION, } \\
\text { ppm }\end{array}$ & $\begin{array}{l}\text { ESTIMATED } \\
\mathrm{MCTE}, \\
\mathrm{ppm} /{ }^{\circ} \mathrm{C}\end{array}$ & $\begin{array}{l}\text { TEMPERATURE, } \\
{ }^{\circ} \mathrm{C}\end{array}$ & $\begin{array}{l}\text { ESTIMATED } \\
\text { EXPANSION, } \\
\text { ppm }\end{array}$ & $\begin{array}{l}\text { ESTIMATED } \\
\mathrm{MCTE}, \\
\mathrm{ppm} /{ }^{\circ} \mathrm{C}\end{array}$ \\
\hline 47 & 327 & 12.1 & 99 & 759 & 9.62 \\
\hline 48 & 338 & 12.1 & 100 & 767 & 9.60 \\
\hline 49 & 349 & 12.1 & 101 & 776 & 9.58 \\
\hline 50 & 360 & 12.0 & 102 & 783 & 9.55 \\
\hline 51 & 371 & 12.0 & 103 & 790 & 9.53 \\
\hline 52 & 381 & 11.9 & 104 & 797 & 9.50 \\
\hline 53 & 392 & 11.9 & 105 & 804 & 9.46 \\
\hline 54 & 402 & 11.8 & 106 & 812 & 9.44 \\
\hline 55 & 412 & 11.8 & 107 & 818 & 9.40 \\
\hline 56 & 421 & 11.7 & 108 & 825 & 9.38 \\
\hline 57 & 431 & 11.7 & 109 & 831 & 9.34 \\
\hline 58 & 440 & 11.6 & 110 & 837 & 9.31 \\
\hline 59 & 449 & 11.5 & 111 & 844 & 9.28 \\
\hline 60 & 458 & 11.5 & 112 & 850 & 9.25 \\
\hline 61 & 466 & 11.4 & 113 & 856 & 9.21 \\
\hline 62 & 475 & 11.3 & 114 & 862 & 9.18 \\
\hline 63 & 483 & 11.3 & 115 & 867 & 9.13 \\
\hline 64 & 492 & 11.2 & 116 & 873 & 9.10 \\
\hline 65 & 500 & 11.1 & 117 & 879 & 9.06 \\
\hline 66 & 508 & 11.0 & 118 & 885 & 9.03 \\
\hline 67 & 515 & 11.0 & 119 & 890 & 8.99 \\
\hline 68 & 523 & 10.9 & 120 & 897 & 8.97 \\
\hline 69 & 530 & 10.8 & 121 & 902 & 8.94 \\
\hline 70 & 538 & 10.8 & 122 & 908 & 8.91 \\
\hline 71 & 545 & 10.7 & 123 & 914 & 8.88 \\
\hline 72 & 552 & 10.6 & 124 & 920 & 8.85 \\
\hline 73 & 559 & 10.6 & 125 & 926 & 8.82 \\
\hline 74 & 566 & 10.5 & 126 & 933 & 8.81 \\
\hline 75 & 573 & 10.4 & 127 & 939 & 8.78 \\
\hline 76 & 581 & 10.4 & 128 & 946 & 8.76 \\
\hline 77 & 588 & 10.3 & 129 & 953 & 8.74 \\
\hline 78 & 596 & 10.3 & 130 & 959 & 8.72 \\
\hline 79 & 603 & 10.2 & 131 & 966 & 8.71 \\
\hline 80 & 611 & 10.2 & 132 & 974 & 8.70 \\
\hline 81 & 619 & $\begin{array}{l}10.1 \\
\end{array}$ & 133 & 980 & 8.68 \\
\hline 82 & 626 & 10.1 & 134 & 987 & 8.67 \\
\hline 83 & 634 & \begin{tabular}{|l|l}
10.1 \\
\end{tabular} & 135 & 996 & 8.66 \\
\hline 84 & 642 & 10.0 & 136 & 1003 & 8.65 \\
\hline 85 & 650 & 10.0 & 137 & 1011 & 8.64 \\
\hline 86 & 658 & 9.98 & 138 & 1019 & 8.64 \\
\hline 87 & 666 & 9.94 & 139 & 1026 & 8.63 \\
\hline 88 & 673 & 9.91 & 140 & 1034 & 8.62 \\
\hline 89 & 681 & 9.88 & 141 & 1043 & 8.62 \\
\hline 90 & 689 & 9.86 & 142 & 1051 & 8.62 \\
\hline 91 & 697 & 9.83 & 143 & 1059 & 8.62 \\
\hline 92 & 705 & 9.79 & 144 & 1068 & 8.62 \\
\hline 93 & 713 & 9.78 & 145 & 1076 & 8.62 \\
\hline 94 & 720 & 9.74 & 146 & 1085 & 8.62 \\
\hline 95 & 728 & 9.72 & 147 & 1094 & 8.62 \\
\hline 96 & 736 & 9.69 & 148 & 1104 & 8.63 \\
\hline 97 & 744 & 9.67 & 149 & 1113 & 8.64 \\
\hline 98 & 752 & 9.64 & 150 & 1122 & 8.63 \\
\hline
\end{tabular}


Figure 7 compares the pooled experimental expansion data with the smoothed data and the cubic spline fit. The relative residuals of the spline fit are shown in Fig. 8. It can be seen that the estimated expansion values from the spline fit are within $0.2 \%$ of the smoothed data.

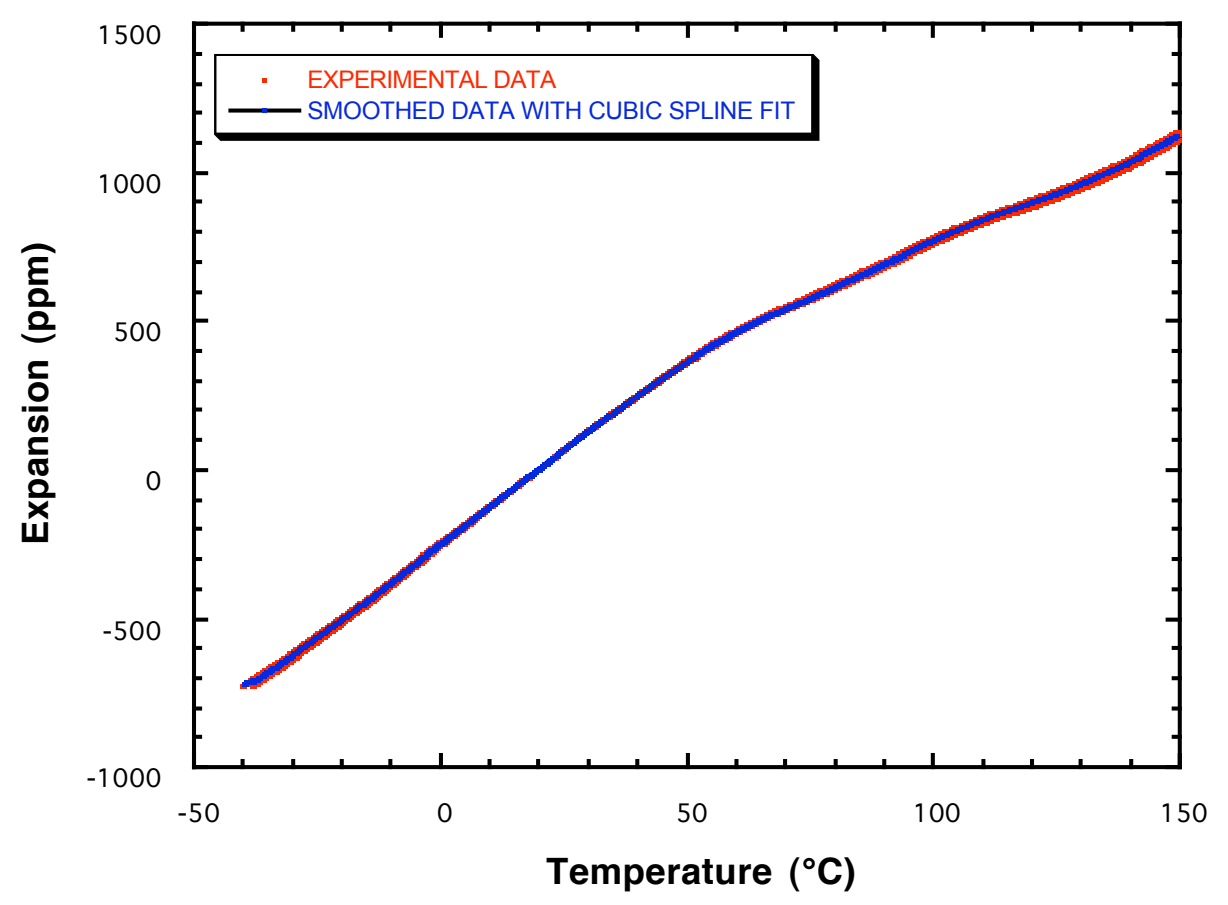

Fig. 7. Comparison of smoothed data and cubic spline fit of smoothed data to raw pooled experimental data for thermal expansion of Type 277-4 cement material as a function of temperature.

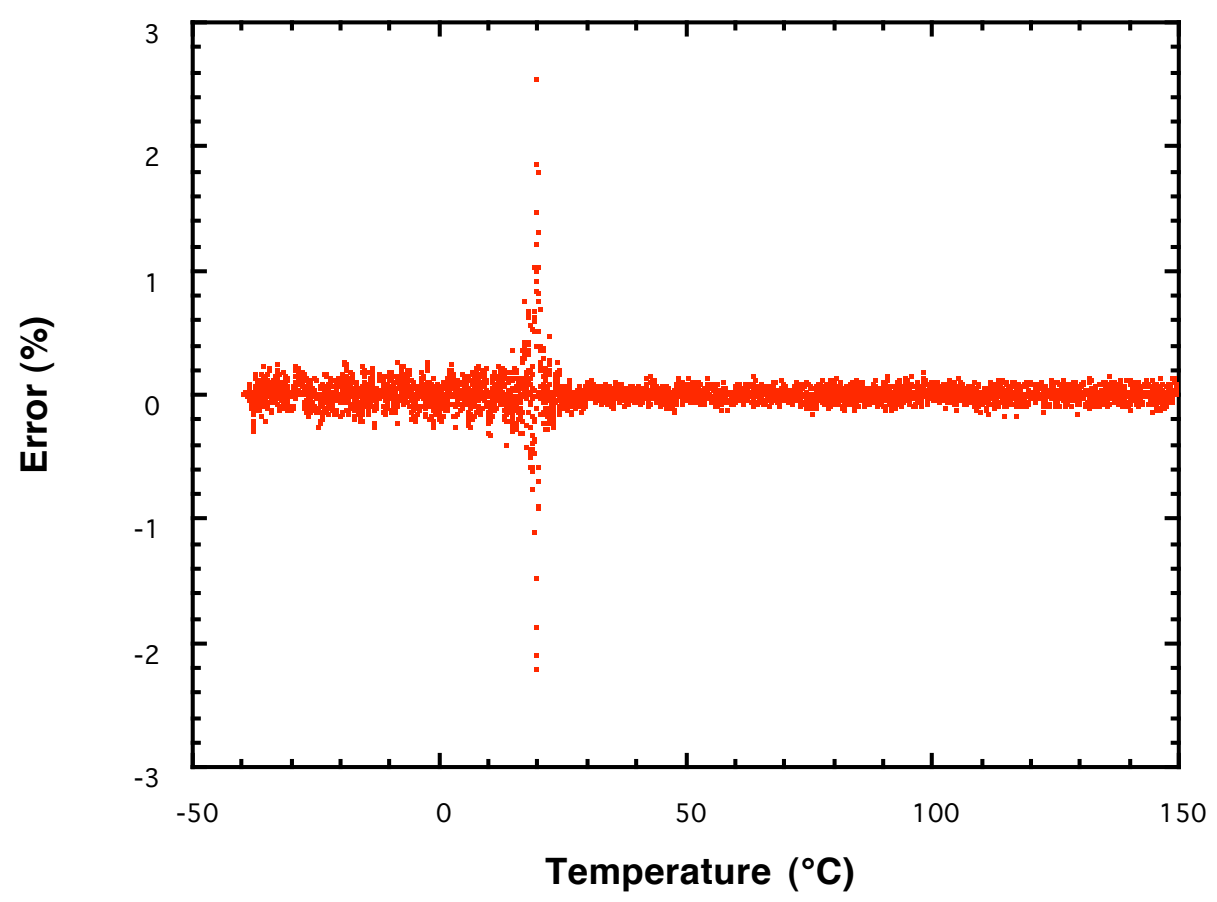

Fig. 8. Relative residuals of cubic spline fit used to estimate expansion values tabulated in Table 5. 
The estimated expansion at the $1{ }^{\circ} \mathrm{C}$ increments was used to calculate the MCTE values shown in Table 5. The value of MCTE at $20^{\circ} \mathrm{C}$ cannot be calculated because of a division by zero condition; therefore, the average of the 19 and $21^{\circ} \mathrm{C}$ MCTE values is listed in Table 5. Figure 9 shows a plot of the MCTE values from Table 5 along with a $9^{\text {th }}$ order polynomial used to fit the values. The MCTE at any temperature in the range -37 to $150^{\circ} \mathrm{C}$ can be calculated using

$$
\begin{aligned}
\operatorname{MCTE}\left(\mathrm{ppm} /{ }^{\circ} \mathrm{C}\right)= & 12.699164-0.0073715235 * \mathrm{~T}+0.00018778752 * \mathrm{~T}^{2} \\
& +1.517514 \mathrm{e}-05^{*} \mathrm{~T}^{3}-6.6945913 \mathrm{e}-07 * \mathrm{~T}^{4}-2.4414824 \mathrm{e}-09 * \mathrm{~T}^{5} \\
& +2.7529257 * \mathrm{~T}^{6}-3.4686036 \mathrm{e}-12 * \mathrm{~T}^{7}+1.7626873 \mathrm{e}-14 * \mathrm{~T}^{8} \\
& -3.2800845 \mathrm{e}-17 * \mathrm{~T}^{9}
\end{aligned}
$$

It is strongly cautioned that Eq. (2) cannot be used to extrapolate MCTE values outside the measured range and describes the behavior only during an initial heating. Figure 10 shows the relative residuals for Eq. (2) using 8 significant digits for the polynomial coefficients compared to the MCTE values from Table 5. It can be seen that Eq. (2) generates the MCTE values of Table 5 to within better than $1 \%$ over the temperature range measured in this study.

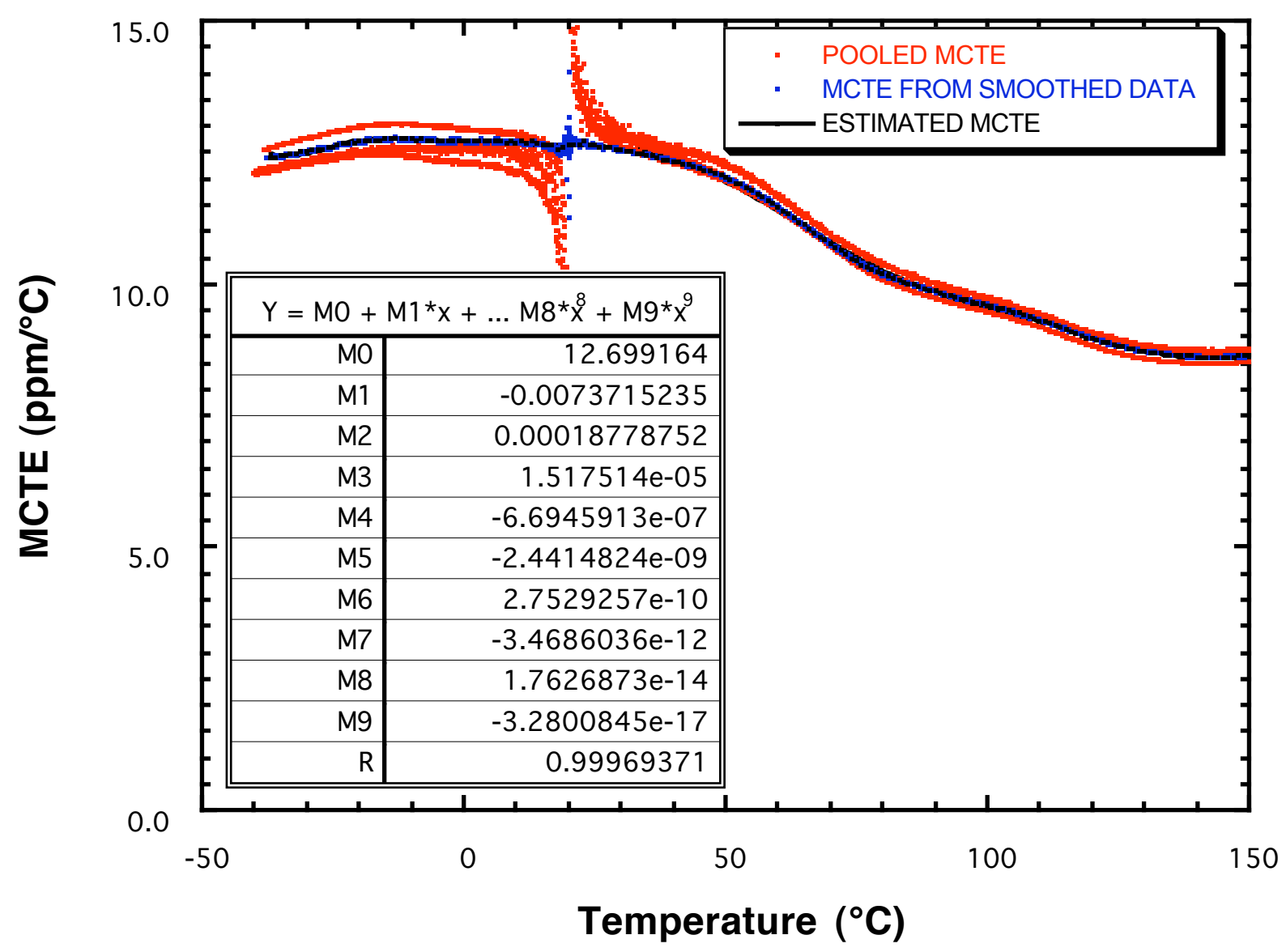

Fig. 9. Comparison of MCTE calculated from estimated expansion with MCTE calculated from smoothed expansion data and raw pooled MCTE values. Also shown is a $9^{\text {th }}$ order polynomial fit of the MCTE calculated from the estimated expansion values of Table 5. 


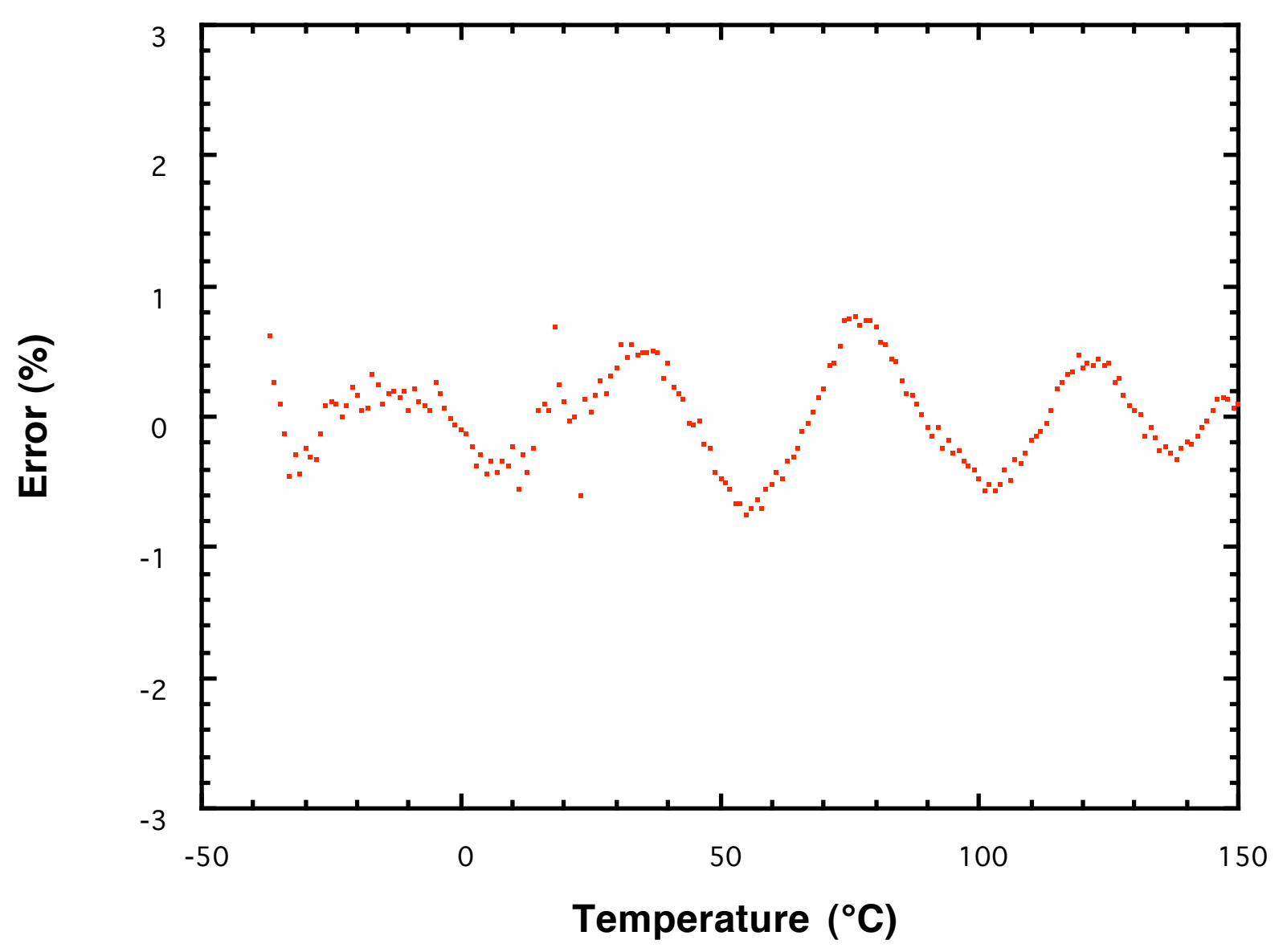

Fig. 10. Relative residuals of the $9^{\text {th }}$ order polynomial fit of the estimated MCTE values using 8 significant digits for the coefficients as shown in Eq. (2).

After non-reversible behavior was demonstrated by the first specimen tested, the remaining four specimens were weighed before and after the expansion testing to determine any changes in mass resulting from heating the specimens. All specimens exhibited a weight loss of $\sim 1.3 \%$ with individual results shown in Table 6 . The initial density for the specimens tested is listed in Table 7. The Lot 1 specimen (Run \#4) appeared to have a higher density than the Lot 2 specimens.

Table 6. Weight loss (\%) behavior during testing

\begin{tabular}{|c|c|}
\hline Run \#1 (Lot 2, Specimen 1) & Not measured \\
\hline Run \#2 (Lot 2, Specimen 2) & -1.39 \\
\hline Run \#3 (Lot 2, Specimen 3) & -1.24 \\
\hline Run \#4 (Lot 1, Specimen 1) & -1.29 \\
\hline Run \#5 (Lot 2, Specimen 4) & -1.34 \\
\hline
\end{tabular}


Table 7. Initial density $\left(10^{6} \mathrm{~g} / \mathrm{m}^{3}\right)$ of specimens tested

\begin{tabular}{|c|c|}
\hline Run \#1 (Lot 2, Specimen 1) & Not measured \\
\hline Run \#2 (Lot 2, Specimen 2) & 1.47 \\
\hline Run \#3 (Lot 2, Specimen 3) & 1.50 \\
\hline Run \#4 (Lot 1, Specimen 1) & 1.60 \\
\hline Run \#5 (Lot 2, Specimen 4) & 1.48 \\
\hline
\end{tabular}

\section{SUMMARY}

Two thermophysical properties, thermal conductivity and volumetric specific heat, were measured using the Hot Disk ${ }^{\circledR}$ method. The results among three random pairs of samples are consistent. All the specimens exhibited the same variations as a function of temperature.

The thermal expansion behavior was determined using a push rod dilatometer. Two specimens were considered to be outliers. Data from the remaining 3 specimens were pooled and the MCTE was described by a $9^{\text {th }}$ order polynomial equation to within $1 \%$.

All specimens lost about $1.3 \%$ during the expansion testing. Measured density of the specimens was found to be about $1.50 * 10^{6} \mathrm{~g} / \mathrm{m}^{3}$ for Lot 2 and about $1.60 * 10^{6} \mathrm{~g} / \mathrm{m}^{3}$ for Lot 1 .

Since the material tested in this study undergoes irreversible changes the first time it is heated above $50^{\circ} \mathrm{C}$, the data reported is valid only for the first time the material is heated above $50^{\circ} \mathrm{C}$ and must not be used to describe subsequent heating cycles.

\section{REFERENCES}

1. S.E. Gustafsson, E. Karawacki and M.N., Khan, J. Phys. D.: Appl. Phys. 12, 1411(1979).

2. S.E. Gustafsson, Rev. Sci. Instrum. 62, 797(1991).

3. V. Bohac, M.K. Gustavsson, L. Kubicar and S.E. Gustafsson, Rev. Sci. Instrum. 71, 2452(2000).

4. ASTM E-228-95, "Standard Test Method for Linear Thermal Expansion of Solid Materials With a Vitreous Silica Dilatometer," Annual Book of Standards Vol. 14.02, ASTM International, West Conshohocken, PA(2003). 



\section{INTERNAL DISTRIBUTION}

1. C. M. Amonett, 9111, MS8201

2. J. C. Anderson, 9113, MS8208

3. J. G. Arbital, 9113, MS8206

4. P. A. Bales, 9113, MS8206

5. E. E. Bloom

6-7. G. A. Byington, 9111, MS8201

8. S. N Cramer, 9113, MS8208

9. M. D. Crenshaw, 9110, MS8238

10. J. F. DeClue, 9110, MS8238

11. R. B. Dinwiddie

12. G. W. Eckert, 9119, MS8234

13-14. M. L. Goins, 9112, MS8201

15. K. D. Handy, 9201-2, MS8073

16. C. N. Heatherly, 9113, MS8208

17. S. T. Holder, 9113, MS8208

18. C. R. Hubbard
19. D. T. Johnson, 9110 , MS8238

20. D. B. Miller, 9113, MS8206

21. A. E. Pasto

22. R. G. Perkins, 9113, MS8208

23-27. W. D. Porter

28. G. B. Singleton, 9113 , MS8206

29. R. H. Smith, 9110 , MS8238

30. D. P. Sooter, 9111, MS8201

31. S. K. Thomas, 9201-2, MS8073

32. D. A. Tollefson, 9110 , MS 8238

33. S. B. Turner, 9110, MS8238

34-38. H. Wang

39. T. L. Warren, 9113, MS8206

40. Central Research Library

41. ORNL Laboratory Records-RC

42-43. ORNL Laboratory Records-OSTI 